\title{
ATOS DA PERSECUÇÃO COMO PROVA CRIMINAL EM FACE DO PROCESSO PENAL BRASILEIRO
}

\section{ACTS OF PERSECUTION AS A CRIMINAL PROOF IN THE FACE OF THE BRAZILIAN CRIMINAL PROCESS}

\author{
Plínio Antonio Britto Gentil ${ }^{1}$
}

\begin{abstract}
Resumo: São freqüentes as condenações criminais baseadas exclusivamente nas informações prestadas em juízo por agentes do Estado que praticaram os atos iniciais da persecução. Há contudo vedação expressa do artigo 155 do Código de Processo Penal a que se condene apenas com os elementos da fase pré-processual. Aqui se sustenta que, mesmo produzidos judicialmente, trata-se de simples reprodução do quanto fizeram esses agentes na prática daqueles atos iniciais e, portanto, não possuem natureza de prova. A sistemática do processo penal brasileiro, com seus princípios e ainda considerado o modelo acusatório para colheita de prova, desautoriza a caracterização de tais informações como elementos aptos a formar a convicção judicial para condenar. O processo é instrumento de defesa da liberdade, por isso não são admissíveis condenações por presunções. Iniciativas legislativas propondo um juizado de instrução e ampliando a participação do advogado na produção de provas podem constituir o germe de um novo panorama que supere este problema.
\end{abstract}

Palavras chave: Prova Criminal; Atos da Persecução; Elementos Informativos; Processo Penal; Juizado de Instrução.

Abstract: Criminal convictions are often based exclusively on information provided in court by state agents who practiced the initial acts of persecution. However, acording to article 155 of Brazilian Criminal Procedure Code, there is an explicit prohibition to condemn based only on the elements of the preprocedural phase. On this paper, it is sustained that, even produced judicially, it is a simple reproduction of the acts those agents did in the practice of those initial acts and, therefore, they have no nature of proof. The systematics of the Brazilian criminal procedure, with its principles and considering the accusatory model for collecting proof, disallows the characterization of such information as elements capable of forming the judicial conviction to condemn. The process is an instrument for the defense of freedom, so convictions for based on presumptions are not admissible. Legislative initiatives proposing a proof producing court and the broadening of the lawyer participation in the production of proof can be the germ of a new panorama that overcomes this problem.

Keywords: criminal proof; Acts of Persecution; Informative Elements; Criminal Proceedings; Proof Producing Court.

\section{INTRODUÇÃO}

Trata-se de pesquisa que tem o objetivo de analisar a aceitação dos elementos produzidos durante a persecução criminal como prova bastante para uma futura condenação, independentemente do aporte de outros, porventura obtidos na fase de instrução judicial. Cuida-se, mais especificamente, dos relatos feitos em juizo pelos agentes do Estado, os quais, nesta condição, atuaram nos atos iniciais da persecução.
É conhecida a freqüência com que, arrolados como testemunhas de acusação, policiais e outros funcionários comparecem ao juízo da causa, onde simplesmente repetem as narrativas já feitas na fase de inquérito - e a propósito dele -, que foram utilizadas para formação da opinio delicti do promotor - no caso da ação penal pública para oferecimento da denúncia. Como regra quase geral, à míngua de divergências entre tais depoimentos, eles costumam ser empregados pelo

\footnotetext{
${ }^{1}$ Doutor em Direito Processual Penal (PUC-SP) e em Fundamentos da Educação (UFSCar). Professor concursado de Direitos Humanos (PUC-SP) e de Direito Penal (UNIP-SJRio Preto). Integrante do Grupo de Pesquisa “Educação e Direito" da UFSCar. Procurador de Justiça criminal no Estado de S. Paulo. Autor de obras de Direito e Educação. pabgentil@pucsp.br
} 
juízo como constituindo prova da infração e de sua autoria, conduzindo à condenação.

Seguem-se recursos da defesa, dirigidos ao tribunal, ao qual se pleiteia absolvição por insuficiência probatória, o que obriga os graus superiores do Poder Judiciário a tomar posição sobre o assunto. Vê-se como majoritário, nesse campo, o entendimento de que os elementos trazidos pelos agentes públicos configuram prova bastante para certificar o crime e sua autoria, aptos, portanto, a sustentar a decisão condenatória. Existem arestos em sentido diverso, mas são visivelmente minoritários. É interessante notar que o bordão da jurisprudência dominante usa o argumento segundo o qual não há impedimento legal a que policiais prestem depoimento. Do outro lado, para os julgamentos que recusam a suficiência desses depoimentos como prova, o que mais se vê é o argumento de que esses funcionários não são isentos em suas versões porque participaram dos atos de persecusão.

Ora, entende-se possível que haja mais fundamentos a considerar além dessa recorrente argumentação do Judiciário, em suas diversas instâncias. O primeiro fundamento limita-se a repisar o óbvio (que policiais não estão impedidos de depor) e o segundo parte de uma presunção sem quaisquer dados objetivos a sustentá-la. $\mathrm{Na}$ realidade, tudo está a indicar que o problema se associa a princípios processuais, ancorados em direitos fundamentais, e ainda relacionados ao tipo de processo penal brasileiro. Em suma, a questão deve ser enfrentada no contexto do processo penal brasileiro, entendida a expressão como significando um sistema uno e coerente, no qual convergem valores, princípios e normas, orientados para um mesmo fim. Assim é que toda interpretação deve partir de uma visão sistêmica e há de considerar uma idéia de unicidade e de totalidade, caracterizadora do processo penal brasileiro como sistema. Ponto crucial nessa abordagem é o disposto no artigo 155 do Código de Processo, que veda ao juiz condenar utilizando exclusivamente os elementos produzidos na fase pré-judicial, ou seja, no inquérito.

Nestas circunstâncias, o que interessa à pesquisa é investigar em que proporção tal entendimento dominante se relaciona com esse nosso processo penal, mais especialmente em vista dos seus princípios de matriz constitucional - e de índole nitidamente garantista; e também a partir de onde pode estar com eles em confronto, assim como com o modelo do processo penal vigente e, especialmente, com a vedação expressa de se proferir condenação fundamentada unicamente nas informações colhidas no inquérito. Em termos mais objetivos, se é possível ao julgador considerar tais informações, ainda que indiretamente, como prova criminal apta a justificar uma condenação. Cuida-se de pesquisa bibliográfica, dedutiva.

\section{PROCESSO PENAL: UM SISTEMA COM FINALIDADE E PRINCÍPIOS}

Princípios, que se apoiam em valores, significam eixos determinantes de interpretação da norma e de indicação da conduta ante essa interpretação, servindo de guias para a criação de normas, sua compreensão e final aplicação. $O$ processo penal compõe-se de comandos com certas finalidades. No dizer de Aury Lopes Jr (2007, p. 371), 
existe uma íntima e imprescindível relação entre delito, pena e processo, de modo que são complementares. Não existe delito sem pena, nem pena sem delito e processo, nem processo penal senão para determinar o delito e impor uma pena.

Está claro que o processo, que é instrumento para o alcance de um fim, determina procedimentos cujos contornos estão sinalizados por princípios. Um deles é o da ampla defesa, que tem, como sabido, previsão constitucional (art. $5^{\circ}$, LV). Quer significar que se deve assegurar a utilização de todos os meios de defesa lícitos e, ainda, o exercício de uma defesa suficiente. Por conta disto é que, dentre outras coisas, todo réu terá direito a ser assistido por um advogado, toda prova lícita é admitida e até mesmo, em certas circunstâncias, para lhe fazer prova favorável, a que tiver sido obtida ilicitamente; e ainda que incumbe ao juiz, se perceber indícios de inocência do réu, procurar elementos que sustentem essa possibilidade, atuando, neste caso, como verdadeiro investigador, o que não pode fazer em benefício da acusação. Acerca dessa incumbência do juiz, confira-se anotação de GENTIL (2008, p. 150) :

[...] a discussão sobre o limite dos eventuais poderes instrutórios do juiz tem se avolumado, havendo já quem sustente que, em razão do perfil acusatório do nosso processo penal, que os artigos 209 , caput, e $\int 1^{\circ}, 234$ e 242 , do $\mathrm{CPP}$, não foram recepcionados pela Constituição. Subscrevendo esses limites da atuação judicial na busca da prova acusatória, mas não de defesa, está a opinião abalizada de Geraldo Prado.

Também o princípio do contraditório, referido pelo artigo $5^{\circ}, \mathrm{LV}$, da Constituição Federal, é de interesse do tema. Cuida-se de complemento ao princípio da ampla defesa, por significar garantia do pleno exercício do direito de defesa - verdadeiro dever de defesa - feita por advogado capaz e diligente, ao qual se devem assegurar todos os meios para tal função, deferindo a produção de provas pertinentes - e motivando racionalmente eventual indeferimento -, e lhe garantindo a palavra depois do acusador, a cujos argumentos poderá contrapor sua posição em favor do réu. Conforme dito por Luís G. Grandinetti C. de Carvalho, remetendo a J. C. Mendes de Almeida e a Carnelutti, o princípio do contraditório alcança "a faculdade de alegar, a faculdade de demonstrar e o direito de ser cientificado dos atos processuais." (2006, p. 142).

Igualmente se relaciona a este assunto o princípio do devido processo legal, também contido na Constituição da República (art. 5, LIV). Ele determina a necessidade de estrita observância do procedimento legalmente estabelecido para a validez de qualquer condenação. Daí decorre logicamente que não poderá haver julgamento se não houver processo e que este, para ser considerado válido, deve seguir rigorosamente as normas procedimentais anteriormente postas, que estejam em vigor. A presunção de inocência é outro princípio processual de raiz constitucional, a indicar que ao acusador incumbe provar, que a dúvida favorece o réu e que é impossível condenar por mera suposição. O raciocínio dedutivo fica limitado pelo que se produziu, objetiva e tempestivamente, nos autos, como prova. Importantíssimo destacar que a prova deverá estar materialmente contida nos autos, excluindo-se a possibilidade de condenação baseada exclusivamente na intuição do juiz, ou no mero senso comum, retirados da experiência cotidiana. 
Ainda é preciso considerar que o processo criminal, de maneira geral, conhece dois modelos ou sistemas - relativamente a quem compete produzir prova. São o inquisitivo e o acusatório.

O sistema inquisitivo é aquele segundo o qual o agente do Estado que julga, e pode ainda executar a sanção contra o condenado, é o mesmo que investiga e obtém a prova que vai sustentar essa condenação. Aí estão juntos e a cargo dos mesmos agentes, o início e o fim do processo: os atos iniciais de persecução, assim como toda a investigação e o poder decisório, constituem papel do mesmo ator. No dizer de Vicente Greco Filho, "é fácil verificar como o sistema inquisitivo não convém à distribuição da justiça, em virtude do comprometimento do magistrado com a acusação que ele mesmo formulou" (1999, p. 72).

Sistema diverso é o acusatório. De certa forma resultado da própria tripartição de poderes, ele pressupõe que a imparcialidade de quem julga não combina com o esforço de quem deve buscar a prova dos fatos. Não podem, portanto, ser funções exercidas pelos mesmos agentes ou poderes do Estado. Surge aí o Ministério Público, capacitado para exercer o direito de ação penal e, em juízo, constituir-se no produtor da prova acusatória - mas nunca fonte de prova. Este é o modelo em direção ao qual transita, mercê de reformas legislativas, o nosso processo penal.

Por último, é caso mesmo de se indagar qual a função principal do processo, dado que ele surge historicamente como garantia de que nenhuma condenação será proferida sem seguir o rito de normas que assegurem os direitos fundamentais das partes envolvidas, especialmente o acusado. Veja-se ponderação do Min. Celso de
Mello, decano do Supremo Tribunal Federal, em julgado tirado no $\mathrm{HC} \mathrm{n}^{\circ}$ 73.338-7 $-\mathrm{RJ}$, em 07/11/1989, in DJU de 14/08/1992F:

\begin{abstract}
A persecução penal rege-se, enquanto atividade estatal juridicamente vinculada, por padrões normativos, que, consagrados pela Constituição e pelas leis, traduzem limitações significativas ao poder do Estado. Por isso mesmo, o processo penal só pode ser concebido - e assim deve ser visto - como instrumento de salvaguarda da liberdade do réu. [...].
\end{abstract}

$\mathrm{Na}$ direção desse entendimento operam as normas processuais no sentido de limitar o poder estatal, o que se harmoniza com eventuais ressalvas, explícitas ou implícitas, à valoração como prova de elementos que aportam aos autos e ao conhecimento do juiz.

\section{PROVA TESTEMUNHAL E O PRINCÍPIO DO LIVRE CONVENCIMENTO}

Qualquer pessoa pode e deve prestar testemunho daquilo que conhece, direta ou indiretamente, que tenha pertinência com os fatos tratados num determinado processo. Ou seja, de elementos que possam contribuir para o esclarecimento de tudo quanto interesse ao deslinde da causa e à aplicação da solução devida. Desta regra geral não estão excluídas nem mesmo as crianças e pessoas com comprometimento mental.

A norma processual estabelece algumas exceções, especialmente voltadas a casos em que a obrigação de colaborar com a apuração fica em confronto com outras circunstâncias cuja preservação é de interesse maior. Os agentes do Estado, sejam policiais, guardas municipais, agentes penitenciários ou outros, que participaram ou não das atividades de persecução, podem muito 
bem, e devem, prestar seus depoimentos a respeito do que sabem, desde que não se encontram proibidos disso. Lembre-se de que a proibição de depor constitui exceção e não regra. A possibilidade de depor, para quem atuou na investigação, não significa, todavia, que o juízo esteja impedido de valorar o depoimento de acordo com tal circunstância.

Será viável admitir um depoimento como prova e, simultaneamente, fazer ressalvas a essa prova, notadamente em vista do princípio do livre convencimento do juiz? A resposta há de ser afirmativa. É o que ocorre nas hipóteses em que a própria norma impõe ao julgador um limite ao seu poder de interpretar. Tome-se, por exemplo, o exercício do direito ao silêncio, o qual, por mais que assim deseje o juiz, não poderá ser considerado como elemento prejudicial ao acusado. Como a decisão será obrigatoriamente motivada, o silêncio do réu não constará da motivação que leva ao convencimento do julgador.

Se o juiz não é inteiramente livre para apreciar a prova, importa analisar os contornos do princípio do livre convencimento. $\mathrm{Na}$ verdade, ele surge em resposta ao chamado sistema das provas legais, vale dizer, aquele segundo o qual cada elemento de prova tem um valor previamente fixado; nesta hipótese o julgador é um intérprete da norma e não da prova; esta já foi tabelada num certo nível pela norma e fica vedado ao juiz desconsiderar os graus de valor de cada qual, devendo decidir após realizar uma espécie de operação aritmética, por meio da qual soma ou subtrai valores até alcançar um ponto de convencimento que é dado pela lei, não por seu raciocínio. É o modelo das provas tarifadas.
Desta maneira, é assim que, para se contrapor ao sistema das provas legais, surge o princípio do livre convencimento, que permite ao julgador apreciar os elementos que tem diante de si liberado de determinantes legalmente postas. Daí se usar dizer que "a prova tem valor na proporção do seu poder de convencimento, não do lugar em que se tenha produzido".

Mas ainda que livre para valorar os elementos que tem à sua vista, está o juiz preso aos limites da razão, significando que deve convencerse exclusivamente de acordo com aquilo que é objetivamente perceptível, estando excluídos componentes que, apesar de subjetivamente convencê-lo, sejam cientificamente insustentáveis. Eis um limite à liberdade do juiz na tarefa de interpretar a prova, que não é o único. Outros existem, geralmente fruto da norma legal, como é o caso da já dita proibição de valoração negativa ao silêncio do acusado, além de outras hipóteses em que é vedada a consideração de certos elementos como prova, caso também daqueles obtidos ilicitamente, ou não vindos aos autos em determinados prazos.

Tudo isto demonstra que, ainda que relativamente a dados objetivos, é bastante freqüente a limitação que a norma estabelece à sua valoração como prova por parte do juízo criminal, mesmo considerada a vocação do processo para a descoberta da chamada verdade real. Em outros termos, o que se deseja frisar é que, por tal ou qual motivo, várias vezes o que surge ante o julgador como sendo prova não pode ser assim considerado, por proibição legal. O princípio do livre convencimento é limitado. Isto é, a formação da convicção não deve apenas ser racional, mas 
também ajustada aos limites eventualmente postos pela norma processual.

\section{PROVA É O QUE SE PRODUZ "EM CONTRADITÓRIO JUDICIAL”}

A partir das reformas operadas no processo criminal, iniciadas em 2008, com um conjunto de leis que modificaram o Código de Processo Penal, o artigo 155 desse diploma, por força da Lei n. 11.690/08, passou a ter nova redação, que absorveu o disposto nos anteriores 155 e 157 e reproduziu o princípio segundo o qual "o juiz formará sua convicção pela livre apreciação da prova", como já constava do antigo artigo 157, mas lhe adicionou novo texto, agora assentando que como prova a ser considerada se deverá entender aquela "produzida em contraditório judicial". Foi adiante, consignando que o juiz não poderá "fundamentar sua decisão exclusivamente nos elementos informativos colhidos na investigação", feitas as compreensíveis ressalvas às provas obtidas antecipadamente, nisto incluídas aquelas não repetíveis.

Assim é que a nova redação do artigo 155 dignifica certas diretrizes visivelmente relevantes: primeiro prestigia o princípio do contraditório; depois estabelece que prova a ser considerada como tal é apenas aquela que for obtida em juízo, o que flui da expressão "em contraditório judicial”; além disso e como consequência, que somente os elementos produzidos diante do jui devem ser qualificados como prova; e mais ainda, que a decisão não pode se apoiar unicamente no quanto obtido na fase de inquérito, que identifica com o termo

\footnotetext{
${ }^{1}$ A propósito, importa lembrar a lição de Espínola Filho, de que "a condenação do acusado será o resultado da
}

"investigação"; e, por fim, que esses dados obtidos durante a investigação devem ser interpretados tão somente como "elementos informativos", em reforço à idéia de que não podem, por si sós, constituir prova.

Quer parecer que o legislador, dessa feita, pretendeu solucionar polêmicas ancestrais a propósito da valoração dos elementos obtidos no inquérito e trazidos aos autos, tantas vezes admitidos para fundamentar decisões condenatórias, exatamente por conta do argumento de que "a prova vale pelo seu poder de convencimento e não pelo lugar de onde veio".

Ora, não é bem assim. Existe atualmente sério óbice para que os que se satisfaziam com esse argumento, diante de expresso texto legal impondo um limite objetivo ao entendimento do que seja prova. Importa em que, mesmo que intimamente convencido de coisa diversa, por experiência, intuição, ou o nome que se lhe dê, o juiz não poderá decidir movido por tal convencimento se ele resulta da interpretação de elementos que não possam constituir prova por determinação legal inequivoca; ficará obrigado a ignorá-los e a não considerá-los em sua motivação, pois são inexistentes segundo as normas do processo.

Não se cuida de novidade, pois a lei processual desde sempre vedou ao juízo admitir, para seu convencimento, certos componentes de aceitação expressamente proibida. Limita-se a liberdade do juiz, em favor de um interesse maior, conforme cada situação. Ora, dado que somente o que constituir prova, e não simples elemento informativo, é capaz de justificar uma condenação ${ }^{1}$,

apuração, no processo, de que ficou provada a existência da infração penal [...], para ela tendo [...] responsável [...], 
evidencia-se que o mencionado artigo 155 proibiu terminantemente a prolação de uma sentença condenatória que não seja fundada em prova, isto é, naquilo que tenha sido produzido em contraditório judicial.

\section{A JURISPRUDÊNCIA: AGENTES DA PERSECUÇÃO DEPONDO EM JUÍZO PRODUZEM PROVA?}

Responder essa questão reclama, de início, averiguar a natureza e o valor probatório dos elementos produzidos na etapa da investigação. O que se vê, a despeito da determinação contida no artigo 155 do CPP, é que setores da jurisprudência ainda os consideram como como fundamento de condenações criminais, de novo em virtude do prestígio de que goza a assertiva de que "a prova vale mais por seu poder de convencimento do que pelo lugar onde foi produzida".

Observa-se uma predominância visível da aceitação dos depoimentos de policiais e outros agentes públicos, que atuaram na primeira fase da persecução (geralmente prisão em flagrante), como elemento de prova bastante para a condenação criminal. Vejam-se alguns arestos, vg (grifos do autor):

TJ-PE - Apelação APL 2893763 PE (TJ-PE)

Data de publicação: 02/07/2015

Ementa: [...]APELAÇÃO CRIMINAL. TRÁFICO DE ENTORPECENTES. MATERIALIDADE E AUTORIA COMPROVADAS.DEPOIMENTO DE POLI CIAIS - VALIDADE -

FARTA

PROVA TESTEMUNHAL. RECURSO IMPROVIDO. 1. Estando provadas a materialidade e a autoria delitiva, verificando-se, ainda, a destinação comercial ilícita da droga apreendida, é devida a condenação do réu; 2. Os testemunhos de policiais, não contraditados, são plenamente convincentes e idôneos, não havendo motivo algum para desmerecê-los; 3. Recurso improvido. Decisão Unânime.

PROVA - Depoimento policial - Valor - Validade e suficiência desde que inexistente contradição ou confronto com as demais provas - Análise que se faz em cada caso concreto - $O$ depoimento de policiais, que no cumprimento de sua missão atuam na repressão penal, é tão válido como qualquer outro testemunho - A circunstância de ser policial a testemunba, não afeta, positiva ou negativamente, o valor probante de sua palavra - Precedentes do Col. Supremo Tribunal Federal - Recurso improvido neste aspecto" (Apelação Criminal n. 993.08.043553-7 São Paulo - 16a Câmara de Direito Criminal - Relator: Newton Neves - 09.09.08 - V.U. - Voto n. 5652).

Argumenta-se insistentemente com a prestabilidade dos depoimentos de policiais e com a ausência de proibição para que prestem depoimento. Ocasionalmente se chega até mesmo ao ponto de afirmar que o agente público goza de uma espécie de fépública, que deve ser aproveitada para legitimar o conteúdo de seu depoimento. Veja-se:

\footnotetext{
Já é matéria pacificada nesta Câmara a presunção de veracidade do depoimento dos policiais que participaram das operações que culminam na apreensão de acusados. (TJ-ES - Apelação Criminal APR 35060008014 ES 35060008014 - TJ-ES - Pub. 03/10/2008).
}

Neste passo fica absolutamente esquecido que a dita fé pública do agente estatal se refere aos seus atos de ofício como funcionário, mas não aos que pratica na qualidade de testemunha. Este o único sentido de fé pública - e não o que se lhe dá em arestos como o acima transcrito. Confira-se (grifos do autor), do blogger SUPERPSICOEDUCADOR, 
conforme

disponível

em

$<$ http://superpsicoeducador.blogspot.com.br/20

14/04/presuncao-de-legitimidadede.html>:

Como é de sabença, o rico magistério do saudoso Mestre Hely Lopes Meireles, nos ensina que os atos administrativos são revestidos de alguns atributos, dentre os quais destaco, "presunção de veracidade", "auto-executoriedade" e "coercibilidade". Afirmar, que o agente público, em sua acepção genérica, atuando estritamente em função de seu cargo, estará amparado pelas normas que regem sua atividade pública, em outras palavras, os atos de um agente público, quando de natureza administrativa, gozam dos prefalados atributos, inclusive, "presunção de veracidade", ou fé pública.

Também outra coisa é prestigiar a boa fé das pessoas em geral, em suas afirmações perante os órgãos estatais, ao tratar de seus próprios interesses. Aqui importa observar o contido no Decreto n. 83.936/79, que "simplifica exigência de documentos etc.”. Cuida-se de ato do então chamado "programa de desburocratização", por meio do qual se dispensa o cidadão de apresentar prova de determinadas situações que lhe digam respeito pessoalmente, presumindo-se a sua boa-fé e a veracidade do que afirma. Evidentemente a presunção se refere exclusivamente à relação do declarante com o poder público, não valendo erga omnes. Baseia-se no princípio da boa-fé e evidentemente não chega ao ponto de legitimar declarações capazes de gerar efeito jurídico para terceiros. Passa longe de revestir do caráter de prova judicial tudo quanto dito por uma testemunha. Ou seja, o legislador, mesmo quando pretendeu atribuir veracidade às afirmações de alguém, não foi ao ponto de presumi-la em casos que não os estritamente pessoais, vale dizer, da relação do declarante com o Estado.
De outro lado, é importante considerar que o entendimento dominante tem uma preocupante interface com o problema do alto índice de encarceramento hoje visível no país, no qual a prisão por envolvimento com o tráfico de entorpecentes ocupa elevado percentual. A propósito disto, vem a calhar o seguinte dizer de Sérgio Rodas (<http://www.conjur.com.br/2017fev-17/74-prisoes-trafico-apenas-policiaistestemunhas $>$ ):

mais de $70 \%$ das prisões em flagrante por tráfico de drogas têm apenas um tipo de testemunha: os policiais que participaram da operação. E $91 \%$ dos processos decorrentes dessas detenções terminam com condenação. O problema, para quem estuda a área, é que prender e condenar com base, principalmente, em depoimentos de agentes viola o contraditório e a ampla defesa, tornando quase impossível a absolvição de um acusado.

De fato, trata-se exatamente do que se observa na experiência forense. A instrução processual nos casos de tráfico revela sempre os mesmos - e únicos - elementos: uma alegada denúncia anônima, abordagem policial, a declarada apreensão de droga, o local suspeito onde o acusado estava e a simples repetição disto pelos policiais em juízo. É quanto basta para presumir (não se pode dizer que seja mais do que presunção) o comércio ilícito e assim condenar a penas altas, em regime fechado.

\section{NEM SEMPRE}

A questão é, porém, controversa. Vêem-se, já com certa freqüência, julgamentos nos quais se reconhecem às informações indiciárias uma função específica, unicamente pré-processual e com o caráter de elementos que não podem, sozinhos, ser considerados pelo juiz criminal. Convém observar: 
No processo penal democrático, que deve desenvolver-se sob os auspícios do contraditório e da ampla defesa, como lembra Aury Lopes Júnior, "os atos praticados na instrução preliminar esgotam sua eficácia probatória com a admissão da acusação, isto é, servem para justificar medidas cautelares e outras restrições adotadas no curso da fase pré-processual e para justificar o processo ou o não processo", mas "não podem ser valorados na sentença". 2 (TJSP, 6a Câmara, Rel. José Henrique Rodrigues Torres - Ap. n. 993.07.128144-1 - Com. de Itapetininga - v.u., j. 09/fev./2009).

Ora, é fácil ver que existe, em contraponto ao pensamento que ignora o lugar em que a "prova" foi obtida, um outro entendimento, que toma os elementos produzidos no lugar administrativo, ou seja, na delegacia, na sede da companhia, ou na repartição administrativa - vale dizer, na fase da investigação, ou do inquérito, - como inservíveis para, sozinhos, formar o convencimento do juiz. Ao invés de se estranhar esse pensamento, o que realmente importa notar é que a norma processual vigente, limitadora da valoração que o juiz pode fazer dos elementos que tem, impede que as razões de decidir se fundem exclusivamente naquilo que foi obtido na investigação; não quer isto dizer que tais elementos não possam constituir alguma fonte de conviç̧ão do julgador. Flui do texto do artigo 155 do CPP que podem, sim, servir como base de convencimento, mas que não podem ser a única fonte desse convencimento. Isto é, podem ser utilizados para formar a convicção do juiz e até utilizados como razão de decidir - e condenar -, mas não configuram prova no sentido estrito e legal do vocábulo, de acordo com o citado artigo 155. Diante disso, podem ser considerados como motivação para a sentença uma vez que complementares e em harmonia com alguma prova "produzida em contraditório judicial".

Nestas condições, desde que as informações obtidas na fase administrativa, ou policial, são capazes de influir no convencimento do juiz se em combinação com a prova produzida em juízo, o que se pode dizer daqueles depoimentos que em juízo prestam, porque arrolados pela acusação, os agentes do Estado que atuaram diretamente na investigação? A propósito disto existe na jurisprudência uma enormidade de divergências. Confira-se abaixo um exemplo do entendimento que descarta esses depoimentos como prova, em contrariedade ao argumento recorrente de que "a prova vale por seu poder de convencimento", e também ao de que "policiais não estão impedidos de depor":

As teorizações jurídicas processuais de âmbito criminal não podem levar a ignorar a realidade fática. O policial é o agente operacional da repressão, incorpora a própria repressão e não depõe com a imparcialidade das demais testemunhas, ainda que inconscientemente. Sua visão sobre os fatos, o seu entendimento sobre as circunstâncias que apurou, é do próprio sistema repressor, de que o garantismo constitucional do devido processo legal objetiva proteger. Não se trata de desprestígio do policial, porque na instrução criminal não se carece da prestação de suas contas como agente que o próprio Estado cooptou e treinou para o exercício da atividade repressora, mas sim prova, cujo enfoque, desnecessário seria dizer, é diverso daquela. Dar ao depoimento do policial valor probatório em sede de processo criminal é, na realidade subtrair do acusado qualquer possibilidade de defesa e elevar-se a repressão à condição de absoluta, estabelecendo-se verdadeiro Estado Policial, em contradição com o Estado de Direito, ainda que passe a persecução penal pelo Judiciário, que simplesmente coonestará a ação repressora. (TJSP - $7^{\text {a }}$ Câm. - Ap Crim. n. 826.669.3/6 - Com. de Ribeirão Preto - j. 24/4/2008 - v.u.).

E mais:

\footnotetext{
${ }^{2}$ Sistema de investigação preliminar no processo

penal. Lúmen Júris, 2006, p. 137.
} 
As palavras dos policiais merecem credibilidade, mas não basta o título (exercício da função de policial). Há necessidade de que estas tenham apoio em evidências circunstanciais e testemunhais, sob pena de exaltar-se um registro indiciário como absoluto, infalível e inquestionável. (TJSP - $7^{\mathrm{a}}$ Câm. - Ap. Cr. n. 1.465.651/6 - Com. de Campinas - j. 19/5/2005 - v.u.).

$\mathrm{E}$ ainda mais:

Uma condenação criminal, com todos os seus gravames e consequências, só pode resultar de prova cabal e livre de dúvidas. [...] Por isso, consoante anotou o d. Procurador de Justiça oficiante, Dr. Plínio Antônio Britto Gentil, no judicioso parecer de fls. 140-143, que fica adotado como razão de decidir, [...], “Não é que se entenda estejam tais testemunhas impedidas de depor ou que as provas obtidas por meio de seus depoimentos não sejam válidas. A inviabilidade está na exclusividade de seus relatos como elemento de prova para embasar uma condenação [...]" (TJSP - 15 Câm. - Ap. Crim. n. 993.08.030764-4 - Com. de Sorocaba -Rel. Roberto Mortari - j. 09/dez./2008 - v.u.).

Importa observar que a base para as absolvições, no sentido destes arestos, por vezes é a suposta parcialidade inconsciente dos agentes da investigação, por outras a exclusividade de seus depoimentos como prova apta a condenar. Tudo indica estar este último fundamento associado à maior parte das decisões absolutórias e como seu elemento mais consistente, parecendo frisar a impossibilidade da condenação quando ausentes provas obtidas em juízo.

Assiste-se, paralelamente, ao surgimento de um volume significativo de argumentos, normalmente utilizados em juízo pelas partes, no sentido de que a aceitação pura e simples desses elementos como base para a condenação criminal invalida, na prática, toda a sequência do processo, tornada inútil porque a prova toda é aquela produzida no primeiro ato da persecução. Observe-se, vg, argumentação extraída de peça processual de P.A.B.G. (autos do processo n. 0024029-13.2014, da Comarca de Bauru-SP (grifos no original):

Os depoimentos de agentes da polícia, que atuaram na investigação, mesmo se prestados em juízo, não podem ter natureza de prova, podendo, quando muito, reforçar uma prova já existente e obtida conforme o padrão fixado pelo citado artigo 155. Não é que se duvide da sinceridade das testemunhas policiais. Nem que policiais estejam impedidos de depor, conforme tanto se utiliza para argumentar em contrário. Nem tampouco que se imagine que eles depõem influenciados pelas diligências de que participaram antes. É que esses depoimentos inevitavelmente representarão uma reprodução, em sede judicial, de fatos que já cumpriram a sua finalidade com o oferecimento da denúncia ou da queixa. Eles já não podem ser valorados como prova e sim como elementos informativos que são, pois oferecidos ao juiz pelos próprios protagonistas da ação administrativa estatal de fornecer dados para o titular da ação penal. Não importa que sejam repetidos em juízo, porquanto o lugar, ou a fase procedimental, em que isto se dá não retira a sua qualidade de dados informativos. Ademais, entendimento contrário equivale a conferir ao agente que flagrou eventual prática de crime a se converter em único e absoluto criador do trânsito em julgado da condenação necessariamente vindoura.

Muito dessa argumentação colhe subsídios em algumas decisões judiciais, em segunda instância. Como segue:

As palavras dos policiais merecem credibilidade, mas não basta o título (exercício da função de policial). Há necessidade de que estas tenham apoio em evidências circunstanciais e testemunhais, sob pena de exaltar-se um registro indiciário como absoluto, infalível e inquestionável. (TJSP - $7^{\mathrm{a}}$ Câm. - Ap. Cr. n. 1.465.651/6 - Com. de Campinas - j. 19/5/2005 - v.u.).

Veja-se também, a propósito, sentença prolatada, por R.E.S., no processo n. 0006620 40.2012.8.08.0024 (024.12.006620-4), da 4 $4^{\mathrm{a}}$ Vara Criminal da Comarca de Vitória-ES [sd]: 
A acusação está sustentada única e exclusivamente no depoimento prestado pelo policial militar J. J. O. J., única testemunha ouvida a requerimento do Ministério Público [...]. É bem verdade que os depoimentos de policiais nos processos criminais são prestigiados pela doutrina e jurisprudência. No entanto, tal prova deve ser analisada à luz das demais produzidas nos autos, uma vez que a simples condição de policial não traz garantia de ser o mesmo considerado infalível em suas ações, especialmente naquelas decorrentes da sua função, exercida, quase sempre, em situação de intenso estresse.

Aqui se reclama alguma consonância do que dizem os policiais com o restante da prova, a indicar que apenas os seus depoimentos não podem constituir prova bastante.

\section{POLICIAIS NÃO ESTÃO IMPEDIDOS DE DEPOR (MAS ISTO NÃO BASTA)}

Não é caso de considerar o gasto argumento, utilizado às carradas em decisões condenatórias, de que funcionários, ou mais especificamente os policiais, não estão impedidos de depor. Ninguém sustenta que estejam. Eles podem e devem depor sempre que conheçam fatos relacionados ao caso em questão. Estar autorizado a depor, contudo, como todos em geral estão, não esgota a discussão do assunto nem a soluciona. Tampouco se cuida de pretender que seus relatos não mereçam crédito. Merecem, como o de qualquer pessoa, de quem se deve, em princípio, presumir a boa fé. Também não é caso de imaginar que alguma espécie de impulso inconsciente levaria tais testemunhas a deixarem de ser imparciais ou honestas no que afirmam.

Relevante neste passo é considerar que a fonte da prova, situada no agente administrativo, ou o policial, constitui obstáculo a que os depoimentos, sozinhos e sem qualquer outro apoio, sejam empregados como meio para a formação do convencimento do juiz e sustentáculo de uma decisão condenatória. Isto porque é ao Estado-Administração, no caso específico à polícia, que competem as ações de persecução na sua fase inicial, quando se buscam elementos tendentes a municiar o titular da ação penal para a instauração do processo. Nesta hipótese, ante depoimentos de policiais, o que aí se tem não é propriamente prova judicial, mas uma assertiva que faz referência àquela atividade de persecução por eles desenvolvida na fase pré-processual e cuja função é apenas possibilitar o exercício da ação penal por parte do Ministério Público. Já que atuaram nessa atividade de persecução, os policiais em questão ficam de certa forma vinculados àquilo que conheceram em virtude de terem sido os primeiros protagonistas dessa persecução. Resulta que seus depoimentos serão, forçosamente, mera referência aos atos que praticaram na atividade investigativa, mas nunca prova judicial, naquele sentido exigido pela norma processual.

Têm valor esses depoimentos? Sim. Devese duvidar, em princípio de sua veracidade? Não. Os funcionários da administração e os policiais podem prestar depoimento? Claro que sim. Todavia não é isto que importa. É que, quando prestam depoimento, seja em que lugar for, esses agentes estatais que agiram na fase de persecução, ou investigação, forçosamente se reportarão àquilo que fizeram no curso dessas diligências. Significa que falarão sobre uma coisa que já esgotou a sua função: servir de base para a instauração da ação penal pelo Ministério Público. Sempre serão elementos informativos, jamais prova.

Cuida-se de um panorama que precisa ser considerado sobre o pano de fundo da nova 
redação do artigo 155 do CPP, a frisar a inadmissibilidade de condenação apoiada exclusivamente em elementos informativos, ou seja, aqueles produzidos na fase do inquérito. Quer dizer: a sentença condenatória exige prova e não se há de qualificar como tal o que não tenha sido obtido em contraditório judicial, sendo impossível, por conseguinte, condenar com base apenas nos elementos do inquérito.

Acaso constituiriam prova os depoimentos prestados em juízo por policiais relativamente ao que diligenciaram na fase administrativa, colhendo elementos para a conclusão do inquérito? Não, ainda considerado o fato de que, afinal de contas, os depoimentos foram prestados em juíro. Mesmo assim, esse locus, palco dos depoimentos, não é capaz de convertê-los em prova, pois esta não é a sua essência. É que o teor desses depoimentos é, como não poderia deixar de ser, o relato dos atos praticados na atividade específica. O seu conteúdo equivale ao de um relatório de investigação ou de um depoimento prestado num auto de prisão em flagrante. Embora colhidos em juízo, o seu conteúdo não muda. Consequentemente, representaria burlar a exigência do artigo 155 do CPP a aceitação de tais depoimentos como sendo prova, apenas porque, nos autos, se localizam fisicamente na etapa judicial. Estejam onde estiverem, serão sempre elementos informativos, peças do inquérito.

Vai daí que o depoimento do policial, ou de quem tenha atuado na produção de informações na fase do inquérito, jamais será prova, no sentido exigido pelo artigo 155 do CPP, naquilo que se referir à atividade executada no exercício da sua competência funcional. Constituirá prova, no entanto, quando se relacionar a eventos fora dos limites de sua atribuição específica e desde que o depoente não tenha atuado na obtenção de informações sobre eles.

Isto quer significar que é a fonte de onde se originam que configura o impedimento de que os depoimentos desses funcionários possam ser admitidos como prova. Essa fonte - a polícia - é uma instituição que tem atribuição constitucional de ir à procura de elementos para viabilizar a instauração do processo. Se as informações disto decorrentes, prestadas por seus agentes, foram qualificadas como prova, já não será necessário o processo, em sua fase judicial: sem outras providências, bem poderia a sentença condenatória advir logo após os relatórios da investigação. De certo modo estaria restaurado o processo sob o sistema inquisitivo, afastado o modelo acusatório. Convém lembrar que, neste último, a coleta de provas e a acusação são feitas por um ou mais órgãos distintos daquele que profere a decisão, não competindo a este a produção de provas, mas apenas o julgamento ante o que se produziu e foi colocado à sua frente. É neste sentido que sinalizam as reformas ocorridas no processo penal brasileiro, com apoio em sua matriz constitucional. Por conseguinte, desde que a prova deve ser produzida ante o juiz da condenação - e que somente assim será válida -, tudo quando se obteve na etapa administrativa, do inquérito policial, não poderá configurar prova, ainda que venham a juízo testemunhas que sejam agentes da obtenção dessas informações e que as confirmem: eles apenas estarão reproduzindo, como xerocopiadoras, aquelas informações que já constam dos autos, nos quais foram incluídas numa outra etapa e com um fim 
específico - o de viabilizar a ação penal - que a essa altura já terá sido alcançado.

Vale conferir sentença absolutória, proferida, em 16/dez./2016, por D.M.C., nos autos do processo n. 0009035-74.2016, da Comarca de Osasco-SP, na qual ficou consignado o seguinte:

\begin{abstract}
Ora, a prova acusatória, por ausência de investigação policial, se limita aos depoimentos das testemunhas de acusação, que, diga-se, não presenciaram o réu em atos de mercancia ou com apetrechos típicos para tanto. [...]. Não se pode presumir que testemunhas de defesa sempre mintam e policiais sempre valem a verdade. Aliás, não existe presunção em processo penal. Ou o fato está demonstrado ou não. Portanto, se no decorrer das diligências, os policiais não se acautelam, arrolando transeuntes que tenham presenciado a apreensão de drogas (sobremaneira porque grande parte das apreensões ocorrerem na via pública) ou que ao menos tenham visto o produto de apreensão e o acusado, ou ainda usuários, ou pessoas que tenham presenciado o réu confessar o crime no momento da abordagem (já que tal confissão, por ser conduta antinatural, necessita estar devidamente comprovada), assumem o risco de verem suas palavras contraditadas por outros depoimentos.
\end{abstract}

A sugestão para que policiais arrolem outras testemunhas sinaliza, de fato, para a rejeição de seus depoimentos como suficientes para formar a convicção do juízo no sentido de julgar procedente a acusação. Só com seus depoimentos os fatos não estão demonstrados e tampouco se deve extrair presunção de verdade do que dizem e falsidade dos depoimentos de quem afirme coisa diversa.

\section{RELATÓRIOS DA PERSECUÇÃO COMO PROVA: ESTADO POLICIAL}

A aceitação como prova dos depoimentos de policiais e quaisquer funcionários que atuaram nas diligências de persecução, independentemente de outros elementos, pode levar a uma decisão condenatória para a qual se deu total e absoluto crédito à versão desses funcionários. Essa versão foi assim tornada inquestionável e suficiente, o que significa que, se o raciocínio for utilizado como parâmetro para outras decisões, estará retirada do acusado a menor possibilidade de se defender eficazmente. Exatamente conforme decidido pelo Tribunal de Justiça de S. Paulo, num dos acórdãos acima, ao anotar que "dar ao depoimento do policial valor probatório em sede de processo criminal é, na realidade, subtrair do acusado qualquer possibilidade de defesa [...] (Seção Criminal, $7^{a}$ Câmara)"3.

Essas narrativas apenas reproduzem em juízo os elementos informativos do inquérito. Relatam providências tomadas na fase da persecução. Clara está a afronta ao princípio da ampla defesa se ocorrer mesmo, como vislumbra o acórdão, a subtração da "possibilidade de defesa" para o acusado. Trata-se justamente do que acontece, uma vez que nada poderá fazer o réu ante relatórios de diligências que já foram admitidos para viabilizar o oferecimento da denúncia pelo Ministério Público. Tais diligências - e informações a seu respeito - constituem um fato que já foi valorado pelo titular da ação penal, de tal sorte que a sua mera reprodução em sede judicial nada lhe acrescenta. A admissão como prova de narrativas apenas descrevendo esse fato impossibilita que sejam contestadas, eis que esses relatos prestam-se unicamente para dar verniz judicial àquilo que a lei expressamente afirma não constituir prova.

\footnotetext{
${ }^{3}$ Grifo do autor.
} 
Nesse caso será pelo mesmo motivo também violado o princípio do contraditório. Já se viu que, por mais esforço que faça a defesa, contestar eficazmente a acusação, apoiada na repetição de informações da fase indiciária, é tarefa que estará antecipadamente condenada ao fracasso, considerando que o juízo adotou como paradigma a consideração como prova dos elementos que funcionaram para possibilitar o início do processo. Assim, o direito de contradizer a acusação será exercido apenas formalmente, sem ter qualquer resultado jurídico. Interessante, sobre tais considerações, a seguinte manifestação de Aury Lopes Jr (2007, p. 372):

É importante destacar que atualmente o grande problema do processo penal está nos seus dois extremos: no inquérito policial e na execução da pena. Ambos administrativos e inquisitivos, deixando o sujeito passivo em completo abandono, sendo tratado como objeto e sem as mínimas garantias.

A atenção que se reclama é, portanto, a de não permitir que as providências administrativas $\mathrm{da}$ fase do inquérito, que possuem um fim específico - o de autorizar a instauração do processo, com a propositura da ação, por meio da denúncia transformem-se num ato da fase judicial, como se nela fossem produzidas, somente porque os funcionários ratificaram, perante um juiz, a ocorrência daquelas providências. Segundo parte do já citado acórdão do TJSP,

dar ao depoimento do policial valor probatório em sede de processo criminal é [...] elevar-se a repressão à condição de absoluta, estabelecendose verdadeiro Estado Policial, em contradição com o Estado de Direito, ainda que passe a persecução penal pelo Judiciário, que simplesmente coonestará a ação repressora (Seção Criminal, $7^{\text {a }}$ Câmara).
Na seqüência do que se viu, é de concluir que também se mostra violado o princípio do devido processo legal, considerando que uma decisão condenatória assim tomada, significaria na realidade uma condenação sem processo, visto que motivada apenas nos elementos informativos da fase de persecução, ou em referências a seu respeito, fantasiadas de prova judicial. Nessa hipótese, o Judiciário simplesmente "coonestará a ação repressora" e admitirá um "Estado Policial", o que significa dizer, em outros termos, que ele estaria atestando a sua própria desnecessidade - e inutilidade - de atuar no processo.

Indiretamente se viola, do mesmo modo, o princípio da presunção de inocência. Ele determina que o ônus de provar compete a quem acusa e que não é possível condenar por meras presunções, mas, ao contrário, somente com base em prova. Se prova é aquilo obtido na fase judicial, frente ao juiz, qualquer decisão condenatória apenas amparada em elementos informativos será uma condenação por presunção, o que afronta esse princípio.

Por último, o que ainda se vê é um claro descompasso com o sistema acusatório do nosso processo penal. É que, inobstante o poder que julga não se confundir com a instituição que acusa, aceitar como prova unicamente o relatório das medidas investigativas tomadas na fase de persecução significa elevar os funcionários estatais ao grau de fonte de prova e não apenas produtor de prova. Nessa linha de raciocínio, dado que o Estado que condena é o mesmo que também pode ser a única fonte da prova para essa condenação, estar-se-á indiretamente invalidando as bases do sistema acusatório, aos poucos adotado pelo 
modelo processual brasileiro. Isto seria quase o mesmo que se aceitar que o acusador também pudesse prestar depoimento acerca da sua convicção íntima e, dessa maneira, oferecer ao julgador a prova suficiente para a condenação.

INOVAÇÕES LEGISLATIVAS: A BUSCA PELA LEGALIDADE NA PRODUÇÃO DA PROVA

Certa novidade nesse panorama representa a proposição, que é recorrente, de alteração legislativa contemplando a figura de uma espécie de juizado de instrução, por intermédio do qual a prova seria preferencialmente colhida já frente a órgão com atribuição jurisdicional, validando os elementos de convicção aí produzidos.

O então presidente do Superior Tribunal de Justiça, Nilson Naves, manifestou-se, em 2003, favoravelmente a essa idéia, como consta de <http://www.trt.gov.br/ej/documentos/2003/T ribunaisSuperiores/30-05.htm $>$ e de $<$ https://jus.com.br/artigos/9523/consideracoes -sobre-juizado-de-instrucao-criminal>:

É também inovação, há muito reclamada por nós, a criação do juizado de instrução criminal, que atuaria em delitos de maior potencial ofensivo. A instauração desse juizado, figura ainda inexistente no Direito brasileiro, a par de depender de alterações legislativas, depende de mudanças culturais. Tem ele o propósito de, previamente, desenvolver a instrução investigativa, elucidar todas as circunstâncias, colher todos os documentos e provocar todas as medidas conservatórias necessárias à segurança dos fatos incriminadores e à ação da Justiça. Afinal, não se pode esquecer uma preocupante verdade: enquanto avança e se moderniza o comportamento criminoso, o Estado continua respondendo com métodos e instrumentos obsoletos.
Já tramitou - e foi afinal arquivado - o PL n. 1914/07 (de autoria de deputado Maurício Rands [PT-PE]), cuja ementa afirmava instituir "o juízo de instrução criminal preliminar, alterando a Lei $\mathrm{n}^{\circ}$ 3.689, de 3 de outubro de 1941( Código de Processo Penal), e [dar] outras providências", que recebeu parecer negativo do relator. Também a comunidade jurídica se posicionou majoritariamente contra a propositura. Veja-se em $<$ http://www.conjur.com.br/2008-jun-

02/projeto_juizo_instrucao_criminal_afronta_co nstituicao >:

\begin{abstract}
O ponto crucial da proposta consiste na extinção do inquérito policial de modo que, a autoridade policial, tão logo tome conhecimento de infração penal, deverá garantir a coleta de dados sobre o crime e apresentar imediatamente a vítima, o suposto autor e as testemunhas ao juízo de instrução criminal. [... mas] o número de juízes no Brasil é absolutamente insuficiente [...]. Por outro lado, se se quer extinguir o inquérito policial com o propósito velado de esvaziar, por reflexo, as funções do cargo de delegado de polícia de carreira, que se o faça por emenda constitucional. Por lei ordinária, não. É que a Constituição Federal cuidou de assegurar aos delegados de polícia de carreira não só a gerência do órgão policial, mas a função de polícia judiciária.
\end{abstract}

Atualmente tramita a PEC 89/15, de autoria do deputado federal Hugo Leal, de sua vez apensada à PEC 430/2009, a qual, propondo alterações no sistema de persecução criminal, sugere, dentre outras providências (veja-se texto):

Art. $2^{\circ}$ A Constituição Federal é acrescida do art. 98-A, com a seguinte redação:

"Art. 98-A. Os juizados de instrução e garantias são órgãos do Poder Judiciário, providos por juízes de instrução e garantias, incumbidos da instrução probatória e do controle judicial dos procedimentos investigatórios criminais.

Relatório da Associação Nacional dos Membros do Ministério Público (CONAMP) 
aponta inconstitucionalidades no projeto, de que é exemplo a "promoção" de delegados de policia à função de juízes de instrução e garantia, sem o apropriado concurso. Outra crítica é a de aparentemente excluir a atuação do promotor como titular exclusivo da ação penal pública. Assim se posiciona a Confederação Nacional das Associações do Ministério Público:

(...) A proposta de alteração normativa em questão subverte a essência da jurisdição ao conferir ao juiz de instrução o poder-dever de agir ex officio, relegando princípio basilar da atuação jurisdicional que é a ação do Estado-juiz apenas mediante provocação das partes. Significa isto dizer que o projeto transforma o juiz, na fase preliminar investigatória da persecução, em agente produtor de prova destinada a formar o opinio delicti do Ministério Público, rompendo, portanto, com o primado da imparcialidade do magistrado." (Nota técnica CONAMP n. 08 de 2015).

De outro lado, em depoimento dado ao autor (06/out./2016) pelo Delegado de Polícia B.G.de P., de Minas Gerais, destacou:

Vale lembrar que o inquérito policial não é destinado ao promotor, ao juiz ou ao advogado. Trata-se de colheita de elementos visando a apuração de prática de infrações penais, podendo concluir pela constatação ou não delas. Ou seja, o procedimento não visa à condenação do investigado, mas sim a produção de elementos que apurem e busquem a verdade real dos acontecimentos. Desta forma, é válida a tentativa da instauração de juizado de instrução que agilizará a produção de provas e encurtará o longo caminho da persecução penal, evitando, por exemplo, que tantas pessoas continuem presas.

Sem chegar a tanto, o Estatuto da OAB, modificado pela Lei n. 13.245/16, procura colocar o advogado mais perto do investigado no curso do inquérito. Não se trata de converter a investigação em juízo instrutório, mas a presença do defensor e a possibilidade de ter vista do procedimento podem levar o inquérito a um status diferente do

puro expediente inquisitivo, aí plantando a semente de um contraditório ainda incipiente. Assim é que o artigo $7^{\circ}$ do Estatuto fica acrescido dos itens XIV e XXI, SS 10, 11 e 12. A partir disso, permite-se ao advogado: 1) examinar, mesmo sem procuração, os autos de flagrante e de investigação de qualquer natureza, em qualquer instituição responsável pela apuração de infrações penais, inclusive Ministério Público; 2) ter vista dos autos mesmo que estejam conclusos ao delegado de policia; 3) extração de cópias, tanto em meio físico, quanto digital, e 4) a assistência de investigados no decorrer do inquérito policial (que se torna obrigatória) em atos de interrogatórios, depoimentos e de quaisquer outros que decorram direta ou indiretamente destes, podendo apresentar quesitos etc.

No dizer do advogado criminalista Leonardo Sica, "a norma é um passo fundamental para assegurar a prevalência do Estado de Direito, a importância do direito de defesa e significa mais um passo na eliminação do 'entulho inquisitorial' que ainda permeia as práticas do processo penal no país"

(<http://www.migalhas.com.br/Quentes/17,MI2 32434,51045-

Direitos + de + advogados + no + acesso $+a+$ inquerit os + sao+ampliados $>$ ). Mais do que isto, os novos dispositivos podem inaugurar um outro patamar de investigação, talvez capaz de representar, futuramente, a superação da tensão entre o que seja prova judicial ou meros elementos informativos.

\section{CONSIDERAÇÕES FINAIS}


Prova para condenação é apenas aquela produzida "em contraditório judicial", segundo dispõe o artigo 155 do Código de Processo Penal.

Os atos de persecução praticados na fase pré-processual têm por objetivo apenas instrumentalizar o titular para eventual propositura da ação penal. Resultam em simples "elementos informativos", os quais, apenar por si, são incapazes de constituir fundamento para um desfecho processual condenatório. Esses "elementos informativos" configuram indícios, que, junto a provas obtidas em juízo, podem contribuir para formação do convencimento para condenar. Não mais do que isto.

Os depoimentos dos agentes da persecução, sejam policiais, guardas, agentes penitenciários, ou servidores em geral, tendo atuado na fase inicial da persecução, ainda que colhidos em juízo, não constituem prova, mas tão só elementos indiciários, que podem fortalecer a prova obtida judicialmente, na forma do artigo 155 do CPP, desde que com ela se harmonizem. A questão não é duvidar da honestidade, da imparcialidade, da sinceridade, ou da maturidade dos agentes estatais enquanto testemunhas. Tampouco sustentar que estão proibidos de prestar depoimento. O motivo da rejeição desses depoimentos enquanto base suficiente para a condenação tem natureza objetiva: significa que, independentemente do funcionário - e de eventuais injunções que possa sofrer -, tais depoimentos sempre reproduzirão, em juízo, atos e fatos que esgotaram sua principal finalidade desde que o titular da ação penal ofereceu a petição inicial acusatória (denúncia ou queixa). Nesse momento já não poderão ser considerados prova, mas simples "elementos informativos", uma vez que colocados diante do juiz por quem foi protagonista dos atos iniciais de persecução. $\mathrm{O}$ fato de serem postos em sede judicial não os converte em prova, pois o ambiente processual em que isto ocorre não lhes muda a essência, que é a de "elementos informativos".

Admiti-los como base suficiente, sem mais amparos, para sustentar uma condenação criminal, afronta o processo penal brasileiro, enquanto sistema, no âmbito do qual estão consagrados os princípios da ampla defesa, do contraditório, da presunção de inocência e do devido processo legal, e que caminha no rumo de um autêntico sistema acusatório na colheita da prova. Ao revés, não ofende o livre convencimento do juiz rejeitar esses "elementos informativos" como prova, eis que a legislação, inclusive constitucional, e toda a sistemática processual, são pródigas em balizar e limitar a formação da convicção judicial.

De outro lado é importante considerar o teor das propostas de criação de um juizado de instrução, ou de instrução e garantias, como ora se fala, desde que revestido de características que lhe emprestem conformidade com dispositivos constitucionais que se referem à matéria. A atual PEC 89/15 traz em si tema candente, relacionado principalmente com o papel do delegado de polícia, importando ter presente que sua atuação não deve se confundir com a de um juiz de direito. De seu turno, as alterações promovidas no Estatuto da OAB trazem inovação importante, talvez legitimadora, no futuro, de um juizado de instrução ajustado à necessidade de agilizar a colheita de provas, bem assim à de garantir, sem a mínima exceção, o direito 
de defesa e de preservação da integridade física e moral do suspeito, indiciado, ou acusado.

Por fim, voltando aos atos de persecução, o desejável é que se estabeleça uma rotina de trabalho em que os agentes estatais procurem obter elementos vindos de outras fontes, o que a cada dia se mostra mais viável, ante o rápido desenvolvimento dos meios tecnológicos, para não falar da possibilidade de identificar testemunhas estranhas aos quadros do Estado. Em uma palavra, que investiguem, dando execução a um trabalho de inteligência. $O$ que não se pode aceitar é que a possível dificuldade em obter prova, de acordo com o que legalmente se determina, converta-se em escusa para a falta de investigação suficiente e em permissão ao juízo criminal para condenar com apoio em simples "elementos informativos", que prova não são.

Segundo dito pelo decano do STF e transcrito acima, “o processo penal só pode ser concebido - e assim deve ser visto - como instrumento de salvaguarda da liberdade do réu". Com este norte, que é o do processo penal brasileiro, é que se há de interpretar a lei, formar o convencimento e julgar. É necessário enfrentar o tema da usual e corriqueira condenação por suposições e da freqüente negligência com o exigido pela norma inscrita no artigo 155 do Código de Processo Penal. Há que se julgar como gostaríamos, nós mesmos, de ser julgados.

\section{REFERÊNCIAS}

AgOSTINHO, Luís Otávio Vicenzi de; HERRERA, Luiz Henrique Martim (orgs). Tutela dos direitos humanos e fundamentais. Birigüi: Boreal, 2001 (Coleção UNIVEM).
ARAÚJO, José Osterno Campos de. Verdade processual penal. Curitiba: Juruá, 2006.

BRASIL. Lei ${ }^{\circ}$ LEI N ${ }^{\circ}$ 13.245, DE 12 DE JANEIRO DE 2016. Disponível em: http://www.planalto.gov.br/ccivil_03/_ato20152018/2016/lei/L13245.htm

BRASIL. Superior Tribunal de Justiça. Processos criminais.

CARNELUTTI, Francesco. Derecho procesal civil y penal. Trad. Santiago Sentis Melendo. Sintra: 1971, v. 2.

CASTANHO DE CARVALHO, Luís Gustavo Grandinetti. Processo penal e Constituição. Rio de Janeiro: Lúmen Júris, 2006.

CONAMP. Associação Nacional dos Membros do Ministério Público. Nota Técnica n. 08, de 2015.

ESPÍNOLA FILHO, Eduardo. Código de Processo Penal brasileiro anotado. Rio de Janeiro: Borsói, 1965.

FRANCO, Airton. Projeto do juízo de instrução criminal afronta Constituição. Disponível em: http://www.conjur.com.br/2008jun-

02/projeto_juizo_instrucao_criminal_afronta_co nstituicao.

GENTIL, Plínio Antônio Britto. O tribunal do júri na reforma do processo penal. Revista Jurídica. São Paulo: Escola Superior do Ministério Público de São Paulo, 2008.

GOMES FILHO, Antonio Magalhães. Direito à prova no processo penal. São Paulo: Revista dos Tribunais, 1997.

GRECO FILHO, Vicente. Manual de processo penal. São Paulo: Saraiva, 2015.

LOPES JR., Aury. Revisitando o processo de execução penal a partir da instrumentalidade garantista. Crítica à execução penal. Rio de Janeiro: Lumen Juris, 2007.

MITTERMAIER, C. J. A.. Tratado da prova em matéria criminal. Campinas: Bookseller, 1997.

NASSARO, Adilson Luís Franco. Considerações Sobre Juizado de Instrução Criminal. Disponível em: https://jus.com.br/artigos/9523/consideracoessobre-juizado-de-instrucao-criminal 
NUCCI, Guilherme de Souza. Provas no processo penal. São Paulo: Forense Jurídica Grupo Gen, 2017.

PRADO, Geraldo. Sistema acusatório. Rio de Janeiro: Lumen Juris, 2005.

RODAS, Sérgio. Disponível em http:/ /www.conjur.com.br/2017-fev-17/74prisoes-trafico-apenas-policiais-testemunhas.

SÃO PAULO. Tribunal de Justiça. Processos criminais.
SICA, Leonardo. Entrevista disponível em $<$ http://www.migalhas.com.br/Quentes/17,MI2 32434,51045-

Direitos + de + advogados + no + acesso $+a+$ inquerit os+sao+ampliados $>$

SILVA, Ivan Luís Marques da. Reforma processual penal de 2008. São Paulo: Revista dos Tribunais, 2008.

SILVA, José Afonso da. Curso de direito constitucional positivo. São Paulo: Malheiros, 2017. 